\title{
TEMPORARY USES AS MEANS OF EXPERIMENTAL URBAN PLANNING
}

\begin{abstract}
A B S T R A C T
Contemporary economic, social and cultural trends support interest in temporary uses of properties and urban space. Temporary uses have an experimental character in development and have agreed to have many societal and commercial benefits, including place-making and support of collaborative practices. This article provides a typology of temporary uses' sociospatial conditions and goals. When designed and implemented in urban central areas, currently under-used areas, or areas losing significance, temporary uses are tuned accordingly for intensification, initiation or redefinition of their locations. Four kinds of approaches taken by the public authorities to incorporate temporary uses have also been identified. These are consistent, project-based, centralised-idealistic and best practices approach.
\end{abstract}




\section{INTRODUCTION}

Design studios in vacant shops, beaches in central Paris, gardening in postindustrial waterfront. Changes in cities economic base, attraction on culture-led initiatives, socio-cultural dynamics that nourish novel bottom-up approaches and financial crisis which delay megaprojects, have all brought increased interest in temporary uses as means of urban change. ${ }^{1}$

Temporary use refers to temporary activation of vacant or underused land or buildings with no immediate development demand. In principle, any action that uses a place for other than its common use for a period of time is temporary use. However, we use the concept to distinct those uses that carry a development-orientation, i.e. capacity and goal to explore further potentials of places they are located. Hence, they form a category between momentary events and permanent (re)development. ${ }^{2}$

Traditionally temporary uses have been associated mostly with land-use conversions where opportunities emerge in-between former primary uses and redevelopment of the area for new primary uses, for example, in former industrial and harbour areas. ${ }^{3}$ Temporary uses are often considered "secondary" to functions that could be established to the site later on. Currently, however, the question of hierarchy between "primary" and "secondary" uses is increasingly tricky as the economic restructuring is transforming cities economic base and altering the demand for certain kinds of urban landscapes. Consequently, temporary uses can also come into question when there is no foreseeable demand for "primary" uses or their identification altogether requires new strategies. "Primary" rather connotes those uses, which are familiar to the planning and development system, including established plan notations, typologies, developers, contractors and real-estate market.

Activities of temporary uses can be transient, i.e. take place only once, for a limited time; recurrent, i.e. repeating, for instance annually, like Paris Pláge, bringing beaches to the Seine's river front every summer since 2002. The activities can also be migrant, i.e. the activities may change place from one location to another, as development proceeds, like the temporary-placed New York Trapez School which has changed location repeatedly following phases of Manhattan's Hudson River Park development. The activities can also move to altogether another location. They may also eventually transform into permanent use, usually after becoming very popular and consequently perceived as essential element of the new character of the place. ${ }^{4}$ This is likely to happen to New York Trapez School too. ${ }^{5}$ In all cases, also temporary 
physical structures, such as constructions, furnishings or decorations are involved. Temporary uses may either be formally agreed with the owner of the site or they may be informal. ${ }^{6}$ Historically, temporary uses have been often unplanned, i.e. they have taken shape outside (or preceding) the official planning process. Recently, however, temporary uses have been increasingly incorporated into official planning processes as phases of development.

In this article, a typology of conditions where temporary uses are particularly valuable, and their respective goals, are provided. Also the role of policymakers and urban planners is discussed and four kinds of approaches the public authorities have taken to incorporate temporary uses in urban development are identified. Naturally, the article begins with review of the literature. Throughout the article, the academic discussion is illustrated by several examples of temporary uses in Western and Eastern Europe as well as the USA and Australia.

\section{ACADEMIC INSIGHTS INTO TEMPORARY USES}

The phenomenon of "new" groups appropriating buildings and urban spaces has been part of countless historic urban processes. Furthermore, the specific cultural and semiotic dimensions of that process already have their own history, addressed for example in Raban's Soft City (1974), Zukin's Loft Living (1982) and Gottdiener's Theming of America (1997). However, the current research, planning and policy interest in temporary uses is rather recent. In the European context, an important initiator was the research and development project "Urban Catalysts: Strategies for Temporary Uses - Potential for Development of Urban Residual Areas in European Metropolises" (20012003), led by TU Berlin and funded by the European Community. The project explored temporary uses in Amsterdam, Berlin, Helsinki, Naples and Vienna. Teams in each country and city developed the theme further and published the results, including seminal books Temporary Urban Spaces: Concepts for the Use of City Spaces (2006) and Urban Pioneers (2007). A common finding across the European contexts was that temporary uses are not an exception or marginal issue - they are rather becoming central and strategic components of urban planning, development and management, with clear input in urban cultural and social policies.

In Berlin, Philipp Misselwitz, Philipp Oswalt and Klaus Overmeyer, the initiators of the Urban Catalyst research and development project, have thoroughly explored the potential of temporary uses in various collaborations. 
They argue that while the combined effect of de-industrialisation, flexible production, "just-in-time" logistics which require less storage areas, demographic change and shrinkage of public institutions such as school, army and hospitals leaves increasingly large areas of inner city land vacant, at the same time there is a great demand for affordable space for cultural initiatives and start-ups, thus opening a large-scale structural opportunity for creative temporary uses. Nonetheless, the common interest of real-estate owners and users, or "urban pioneers" exploring the new potential of spaces, is not always easy to find. The process requires mediators and a clear supportive role of the public authorities. In a lack of direct investment resources, public authorities can "initiate and mediate processes" by, for example, assisting in locating sites, relaxing licensing procedures, relinquishing a site on favourable terms, or giving financial advice. ${ }^{7}$ Berlin has had very large vacant areas, because of the combined effect of de-industrialisation and shrinking population. Simultaneously, low rents have invited a large community of young creatives to Berlin, making it a laboratory of innovative ideas and new economy. In this transformation process, temporary uses have played a strategic role. ${ }^{8}$

In Vienna, Haydn and Temel emphasised the critical character of temporary uses, linked to activism and do-it-yourself-mentality of city residents. In a clear distinction to the pragmatic and economic North American use of the term "interim use", in Europe "temporary use" should be seen as an approach to ensure diversity and alternative space provision - "rather than leaving development to government and the economy alone, they explore an appropriation of the city". 9

In Amsterdam, the Urban Catalysts team suggested that the whole of urban space should be seen in new light as "casco" or empty hull, open for endless new opportunities and surprising uses. This vision has proven fruitful, underlined by the recent popularity of urban games, parkour or urban gardening. ${ }^{10}$ NDSM Wharf, one of the main cases of the Urban Catalyst project in early 2000s, has evolved to a successful focal point of urban development of Amsterdam North. In recent years, the "breeding place" and alternative scene of NDSM has got as its neighbours increasingly high-end developments, such as new offices and MTV studios.

In Helsinki, Lehtovuori et al. argued that vacant spaces available for various temporary uses are a condition for cultural renewal in cities. ${ }^{11}$ In Helsinki's early 2000s context of relatively regulated urban development process combined with continued high demand in space, only the slow planning process seemed 
to open opportunities for temporary uses. During the last decade, however, public authorities' attitudes towards temporary uses have changed markedly. Temporary uses and art programmes have become an integral part of several large city-led development projects, and a recognised resource for Helsinki economic development policy towards more diverse creative and servicebased economy. This is not without problems, however, since initiators of temporary uses still face bureaucratic and economic problems. ${ }^{12}$

The scopes and potentials vary greatly depending on the type of transformation the cities are going through. For instance, Ruoppila has pointed that due to the land-use development logic during the state socialist period and therefore the scope of vacant land today, post-socialist cities would have enormous possibilities for temporary uses in reasonably located former industrial areas. Building on Urban Catalyst research, Nicole Blumner has reviewed current demand and practices for temporary uses in German and the US cities. She emphasises these emerging planning tools and techniques as a solution in contexts other than consistent growth and straight-forward programming; "yet vacant spaces have the potential to serve as creative laboratories for a city, if they are allowed to do so", she argues. Researchers at Tampere University of Technology have developed a similar concept and method of "urban fallows" to operationalize temporary uses for development consideration in difficult locations that are falling out of the real-estate cycle, such as modern suburban industrial areas. ${ }^{13}$

Recent research shows that the understanding of temporary uses' benefits has bene spreading. Gerend reports that in the US cities temporary, interim or intermittent uses have become a recognized planning classification. The main motivation is to increase the attractiveness of yet un-built land, but it is also recognised that the uses themselves can become sustaining innovations, incubating small businesses or other organisations. Likewise, discussing the links between urban planning and innovation activity, Ruoppila et al. recognised emerging of particular urban places, which serve as spatial and temporal niches of innovation. ${ }^{14}$ The rough aesthetics of industrial left-over spaces, the appreciation of the un-designed and indeterminate, attracts artists, designers and other creative professionals. Based on empirical work on several temporary "city beaches", a wide-spread innovation in Europe, Stevens and Ambler consider the beaches as a tool to optimize the use of a particular spatial resource before the next cycle of large-scale reinvestment, if it ever materialises. While the recent recession has indeed halted several development projects, Lang Ho notes that some cities and private developers are trying to 
create interim uses for lots standing otherwise vacant. Good example is the "Platoon Kunsthalle", a migrant cultural space in Berlin (with sister projects also in Seoul and Gwangju in South Korea) which stays few years in each lot based on deals with the landowners. Bishop and Williams report in their new book The Temporary City numerous examples of private sector activation from the UK - as well as cases where temporary uses are implemented through planning, organised as phases of development.

There are several good reasons why the interest towards temporary uses has intensified recently, as reported by Bishop and Williams. The current economic development produces vacancies and creates demand for alternative, adaptive strategies that temporary uses provide. The financial crisis has undermined faith in perpetual growth, which has decelerated private investment, but has had an effect also on public spending, consequently cutting investments in urban development. Temporary uses are among adaptive strategies of city dwellers and businesses. Meanwhile industrial restructuring, technological advancements in logistics and commercial restructuration continues to leave behind large areas of vacant land and real estate. Hence, the supply is great for temporary users who "tend to select those sites that are for little interest to property investors at a given time". ${ }^{15}$ Vacancies are increasing also in offices, as flexible office work gains popularity, since the work can be done almost wherever, and it is done increasingly on move. The trend is rather critical examination of floor-space requirements, and intensification through multi-use of different kinds of properties. Meanwhile the uses of popular public spaces are also intensifying along increasing amount of entertainment activities spilling into streets. The practices of various ethnic cultures also bring along intensifying temporary elements. Moreover, the "old" demand of counter-culture and activism, which have traditionally played an important part in temporary uses, continues to do so. In order to flourish, non-profit projects as well as beginning companies require availability of affordable spaces, which the "pioneering" activists search for. The rising significance of creative industries has drawn increasing attention to "creative milieus", for which temporary uses contribute to significantly. A novel advantage is the new technologies which enable spreading the word among communities of interest with a great speed and penetration.

Bishop and Williams argue that these developments form a powerful new trend, "temporary urbanism", by which they mean intensification of temporary uses, which also the planner needs to take notice of, since that might be the greatest potential for urban development in our time. They write: 
"Urban planners need to recognize that this enthusiasm is not incidental but represents an appreciation of experimentation and a willingness to 'see what happens' that is perhaps the spirit of our time. When planners and policy makers start to experiment as well, this could represent a powerful mechanism to retune our cities for whatever lies ahead."16

Similarly, approaching the novel demands from profession perspective, Havik et al. call for new thinking in how the planners and designers can put the contemporary uncertainty to productive use - be it the balance between defining space and leaving open its use, or dealing with the gaps that appear in the traditional practice of urban development. ${ }^{17}$

\section{ADVANTAGES AND REQUIREMENTS}

Aforementioned contributions have pointed out several public and private benefits that temporary uses may provide.

The public or societal benefits, which explain the increased policy interest, are three-folded. First of all, temporary uses are good tool in place-making, i.e. creating attractive, lucrative and active urban spaces, recognised by wider public. On the other hand, temporary uses of properties can provide affordable office or working space for new creative businesses and arts, which indirectly may support innovation activity. Crucial is also that temporary uses are a concrete tool to nourish the bottom-up approaches in exploring potentials of spaces; they are eventually people-created places, which may use and develop collaborative practices.

The private or commercial benefits relate to developing the potential of a location, but also provision of incomes and cutting the costs. Likewise to public benefits, the primary advantage is place-making: the temporary occupiers and activities can have a great effect on attractiveness of a location. The "buzz" that they create may have considerable effect on real estate values, even in a wider area. Moreover, temporary uses have a potential to create considerable impact with minor costs. Another advantage is that the temporary activities can provide a vehicle for local consultation and help to build a bridge between developer and community. Temporary uses can also provide rental income from properties which do not have another demand. In fact, renting space in basic condition may give the investor even a good rental income compared with the small initial investment, which is presumably the case with BIGZ-factory in Belgrade. This is a plausible business model, and 
an alternative to traditional real estate development focussing on refurbishing. That may not even be an option, because many properties occupied by temporary uses are short-listed for protection or have other kinds of planning restrictions, which hinder remodelling. Moreover, renting on basic level does not exclude potential upgrading later on. In cases where the temporary tenants are not able to pay for market rents, their rents provide at least some gain for the property owner, and helps to decrease the maintenance, security and insurance costs of the properties standing otherwise vacant, as well as saving money on vacant property taxes used in many countries. Moreover, non-commercial use can attract commercial uses. For instance, if one part of the property is rented affordably to theatres, another part can be leased to a restaurant with a decent rent.

The first and foremost condition is availability of suitable spaces and the groups who actively seek to use those spaces. Temporary uses are more likely to take place in spaces which provide a particular milieu and atmosphere where the users can build on, in their quest for particular experience of a place. Another basic condition is connectivity and easy accessibility by great number of participants and audiences. Different location types are discussed in the next chapter.

A crucial condition is also trust between the owners and the tenants, which allow the latter to experiment without risk of eviction. One problem is that the tenants are often individuals or small associations or companies, whereas the property owners are institutional. Under such conditions, trust can be supported by forming temporary use associations or alliances, or by establishing intermediary agencies.

To have a backing support by the city is not necessary, but it certainly helps a lot. Among simple things that cities can do to assist temporary uses includes taking head leases to buildings or letting their own property for temporary uses, encouraging establishment of intermediary organisations, support networking, marketing and promotion, or provide databases of vacant properties. However, the policy intervention should be moderate since temporary uses primarily require cheap spaces and freedom from constraints. It is experiment driven development, not planning led, and therefore public authorities should not have a steering role in what happens on those sites. Hence, the desired policy is often "actively letting it be", meaning that measures should focus on conditions, keeping the rents low and guaranteeing accessibility, not on the action itself. ${ }^{18}$ The same is noted by Bishop and Williams: 
"The principal assistance is probably for governments to have the courage to leave areas relatively loosely defined in planning terms, and to use quite specific interventions to make land, buildings or small startup finance available. In this respect there is an argument for the creation of zones of tolerance where government planning and regulations can be more permissive and flexible." (Italics added by us.) $)^{19}$

Public authorities' different approaches to incorporate temporary uses into planning and development of particular sites will be discussed later in the article.

\section{TEMPORARY USES TYPOLOGY: CONDITIONS AND GOALS}

As temporary uses are specific and place-based, literature has provided only few theories on where temporary uses are likely to take place. On general level, the "rent gap" (or "value gap") theory by Neil Smith explains the emergence of locations that are attractive for redevelopment, and thus may be temporarily vacant or in secondary use, waiting for new investment. Especially if the new investment is postponed because of economic uncertainty or problems in planning or heritage status, opportunities for temporary uses may occur. In general, the complex, uneven and uncertain Post-Fordist landscape of urban development is assumed to increase opportunities for temporary uses as well as incentives to promote them. Discussing conditions of "urban mine canaries" - small, often un-profitable cultural and culinary venues that are important for cities' atmosphere and liveability - Söderlind proposes a simple locational theory, arguing that mine canaries can thrive in areas which are simultaneously affordable and accessible. Straightforward commercial city centre renewal schemes that tend to push such "weak uses" away, are harmful for the "soft infrastructure" which the small cultural venues provide for larger and more profitable functions, such as shopping centres and cinemas. Hence, planning and policy that protects "weak uses" are needed. For many temporary users and uses, a parallel argument is relevant: in many cases temporary users are weak actors, for example new start-ups or small cultural groups with limited resources. A public acceptance and support is needed to enable their diversifying role in development.

Almost any urban location can have potential for some kind of temporary use. Urban Pioneers as well as Stevens and Ambler have already made a distinction between central and marginal spaces leading to two different kinds of temporary use. In central locations, the question is how to intensify the use further, even though several practical and legal limitations make new investment difficult. In 
marginal locations, the question is rather how to invite first users to unknown or vacant area or site. However, both cases rely on overall established urbanity and demand or urban growth. To create a comprehensive analytic framework of temporary uses, we propose to take into account a third spatial condition, namely locations losing significance.

These three types of spatial conditions, with different current social attention, apprehension and development perspective, and consequently different goals of temporary uses are shown in Table 1. The three types cover all of the many examples of temporary uses that we are familiar with. To illustrate our point, presented below are few examples of temporary uses in each category.

Table 1 Temporary uses typology: conditions and goals

\begin{tabular}{|l|l|l|l|}
\hline & $\begin{array}{l}\text { URBAN CENTRAL } \\
\text { AREAS }\end{array}$ & $\begin{array}{l}\text { CURRENTLY } \\
\text { UNDER-USED } \\
\text { AREAS }\end{array}$ & $\begin{array}{l}\text { AREAS LOS ING } \\
\text { SIGN I F ICANCE }\end{array}$ \\
\hline USE, FUNCTION & Defined & Not defined, loose & Defined, but weakening \\
\hline $\begin{array}{l}\text { ATTENT ION AND } \\
\text { FLUX OF PEOPLE }\end{array}$ & High & None & Some, could be better \\
\hline $\begin{array}{l}\text { APPREHENS ION, } \\
\text { MEANI I G }\end{array}$ & $\begin{array}{l}\text { Fashionable, classic, } \\
\text { elitist }\end{array}$ & Edgy, daring, promising & $\begin{array}{l}\text { Out of fashion, } \\
\text { low-brow }\end{array}$ \\
\hline $\begin{array}{l}\text { DEVELOPMENT } \\
\text { PERSPECT I VES }\end{array}$ & Stable, lack of new ones & Open (risky) & Redevelopment optional \\
\hline $\begin{array}{l}\text { GOAL OF } \\
\text { TEMPORARY USES }\end{array}$ & Intensification & Introduction, initiation & $\begin{array}{l}\text { Redefinition, } \\
\text { diversification }\end{array}$ \\
\hline
\end{tabular}

Urban central areas

In central locations, where functions are defined, and there are several practical and legal limitations, like heritage conservation, which make new investment opportunities rare, temporary use may provide an opportunity to generate additional income through short-term intensification or multiplication of use. In terms of regulation, temporary interventions are more easily accepted than permanent new structures. In the context of high density, high land-values and investment interests, temporary uses facilitate rapid turn-over of capital. Culturally, experimental temporary uses may provide wanted alternative scenes to the otherwise commercial, sterile or museum-like city centres. 
Paris Pláge, the summertime city beach on the river Seine, is a primary example of temporary diversification and intensification of uses of urban central area. Its success since 2002 has led to the initiation of two other recurrent city beaches in Paris itself and a plethora of projects elsewhere, for example in Berlin and Bristol. ${ }^{20}$

In the post-socialist situation of Central Eastern Europe, Warsaw's Parade Square in front of the Palace of Science and Culture is an illustrative example. After the breakthrough year of 1989, the Stalinistic Square became a test-site of commercial usage, crammed with temporary halls for funfair and markets. In late 2000 s, the temporary structures were cleared to make way for new art museum and assembly area.

The recent pedestrianisation of New York's Times Square shows the power of gradual steps and experimentation as a planning tool. Orchestrated by the Danish architect Jan Gehl, the car-dominated area has been changed to a caféprecinct and urban playground, starting with cheap and light-weight temporary structures and markings on asphalt. The NYC DOT Public Plaza Programme has continued to implement similar transformations all over New York.

In Helsinki, the WDC 2012 Pavilion is an interesting case. The temporary wooden structure, created in collaboration with Aalto University, a large wood product company and the museums of Architecture and Design, provides an event space and a focal point for Helsinki's special year as the World Design Capital. Simultaneously, the structure sends a subtle political message, underlining the need of permanent extension of the adjacent museums.

\section{Currently unused or under-used areas}

In areas, which are out of citizens' "mental map" - such as marginal suburban locations and large underused brownfields, but also more central yet closed industrial or institutional estates - temporary uses may be efficient in inviting first users to an unknown or empty site. The pioneering temporary uses initiate the place-making process, with specific social and economic advantages.

NDSM wharf in Amsterdam North is a prime example of the catalysing power of temporary uses. Supported by the city's "Breeding Places Fund", temporary users have since year 2000 converted the empty and derelict wharf to a major cultural and tourist destination. The success of NDSM has changed the fortunes of the whole of Amsterdam North, triggering a wave of new developments. (See the next chapter for a more detailed description of the case and related policies.) 
Figure 1 Temporary uses in urban central areas

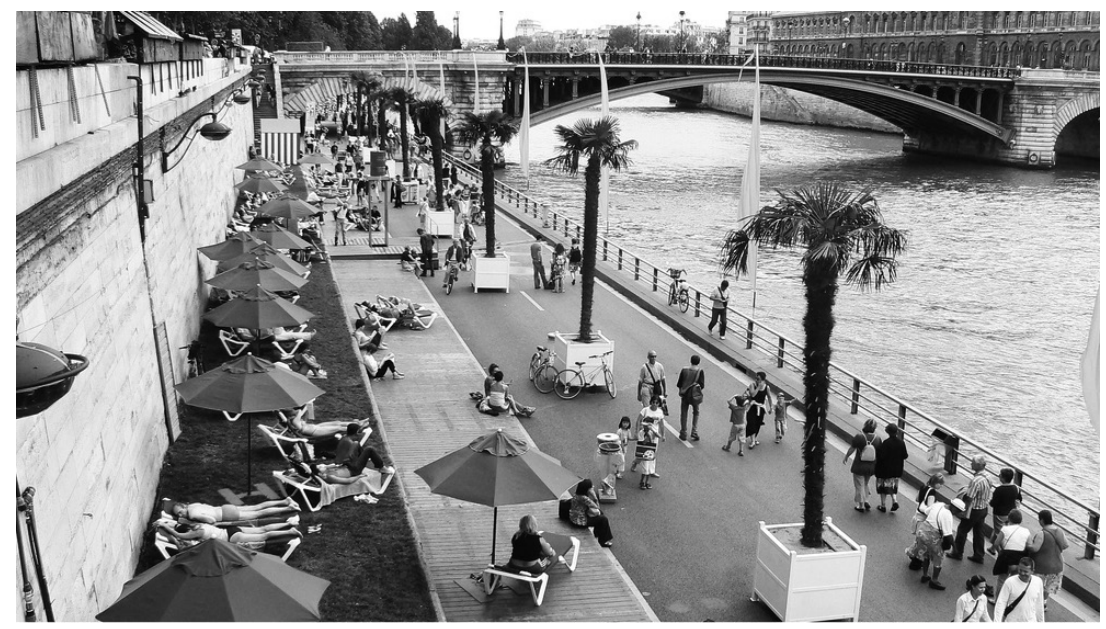

1. 1 Paris Pláge (CC (e)Spry)

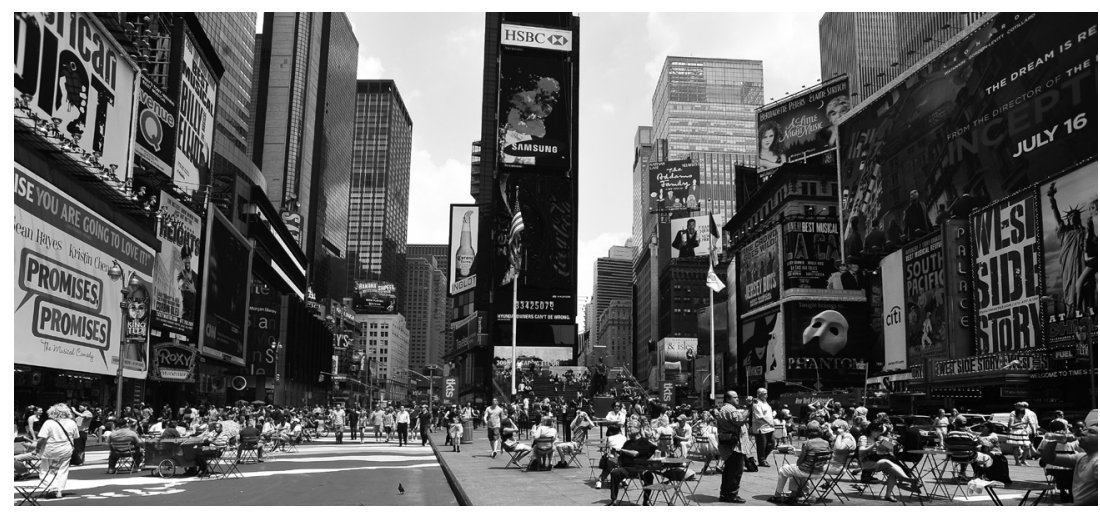

1.2 New York Times Square (CC Asterix611)

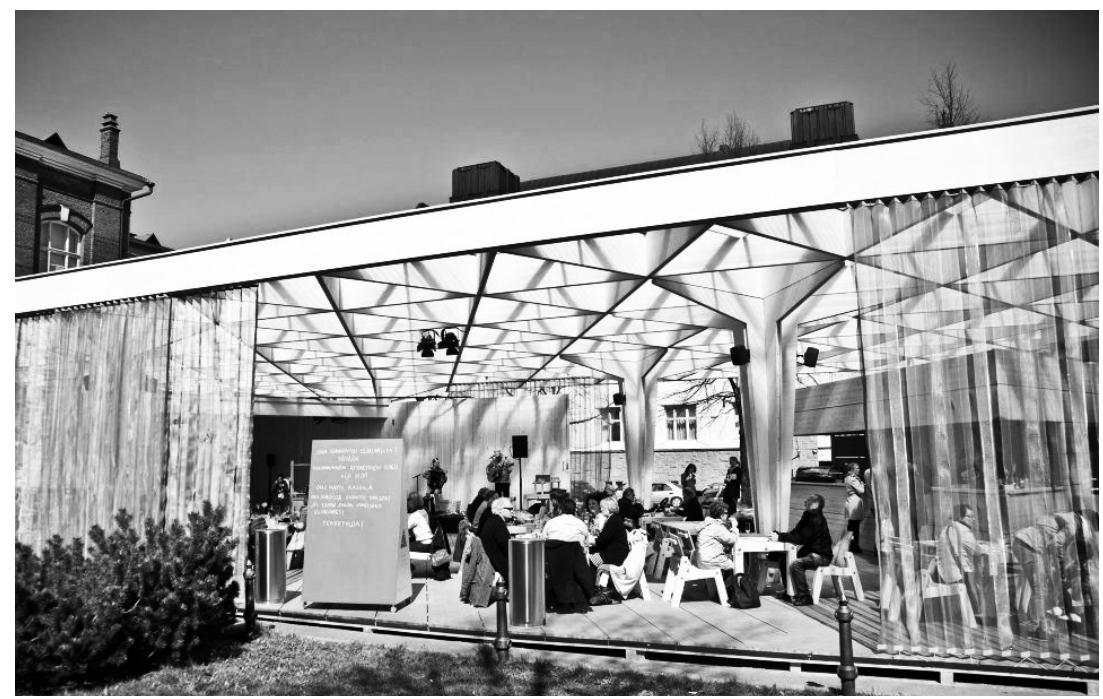

1.3 Helsinki World Design Capital 2012 pavilion (CC eageriseager) 
Former railway station in Plzen, Czech Republic, occupied by independent cultural centre JOHAN Centrum, is an example of property owner waiting for cultural users to "work the property" while no other demand is at hand. The operating NGO, called the Johan Citizen's Association, pays the owner only a marginal rent, but takes care of maintenance of the rather derelict building. The temporary cultural use might however lead to a permanent one, preceded by public and private investments. Plzen has been selected as European Capital of Culture in 2015, and the station is one optional main location for the activities and attention, which would bring along renovation to suit also more institutional cultural uses.

Trapeze School New York is an independent permanent actor that has operated in several temporary locations in Manhattan's west bank as 550 acres of former non-recreational waterfront and piers undergo major phased remodeling to become Hudson River Park. The Trapeze School's location began as a temporary experiment, but became soon such a popular feature in the regenerating waterfront, that it will most likely be reincorporated into the permanent development plan. ${ }^{21}$

Kalasatama Temporary is an art and temporary uses programme, initiated and facilitated by the City of Helsinki since 2010. The site is a large empty harbour area in the Eastern inner city of Helsinki, which is to be developed to a new urban district with 18,000 inhabitants and 10,000 jobs. The aim of Kalasatama Temporary is to support pioneering uses that test opportunities, invite people, start social processes and create publics. The funding comes from developers: each lot acquisition involves a payment of 10 euros per square metre of building right to a special fund of the City of Helsinki. After two very successful years 2010 and 2011, the future of the project is somewhat unclear, valorising the complications of Helsinki's centralisedidealistic temporary use policy (see below).

\section{Areas losing significance}

In areas losing significance, i.e. sites emptying, declining or facing consequences of shrinking of their respective cities or regions, or losing popularity of their location, the temporary uses can be used to dignify the urban life, enhance the quality of urban space and provide new (small-scale or low-profit) business opportunities. Such new uses have proven to be socially and culturally highly important, even though they may not have the power to overturn the negative demographic spiral. 
Figure 2 Temporary uses in under-used areas

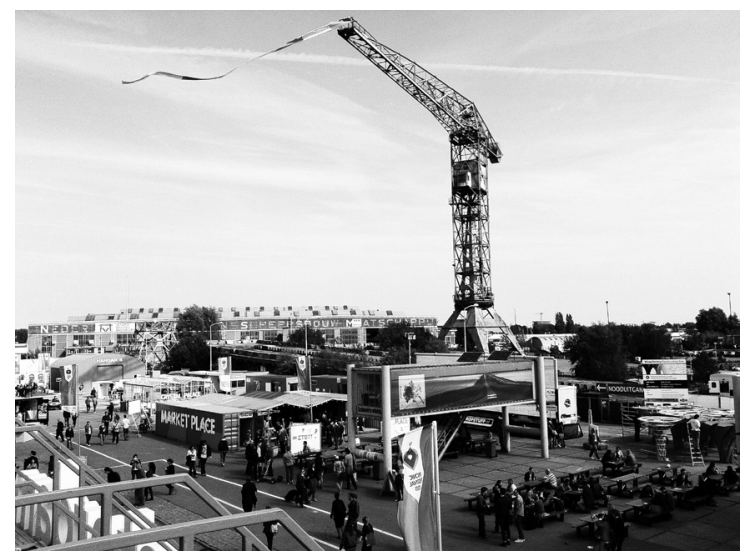

2.1 NDSM Wharf in North Amsterdam (CC andynash)

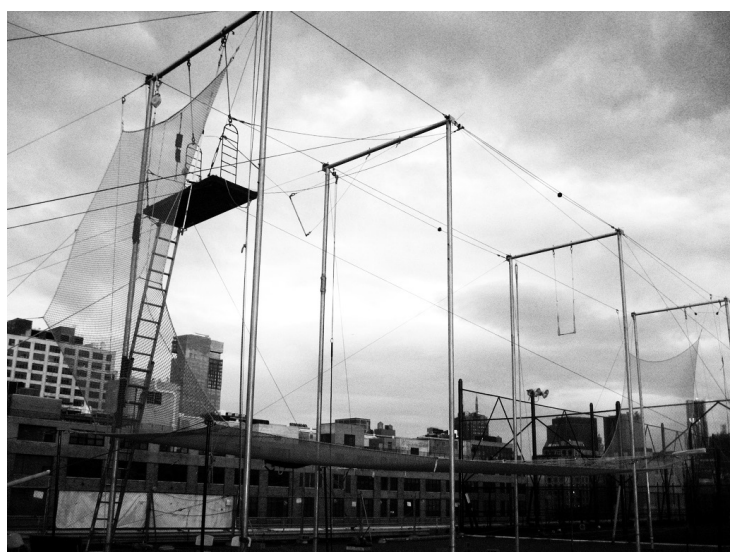

2.2 Trapeze School New York in emerging Hudson River Park, NYC (CC Superfem)

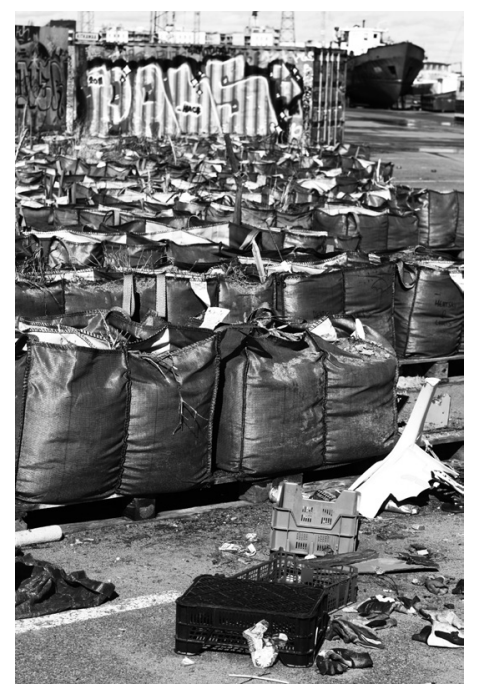

2. 3 Urban gardening in Kalasatama harbour, Helsinki (CC 31S70)

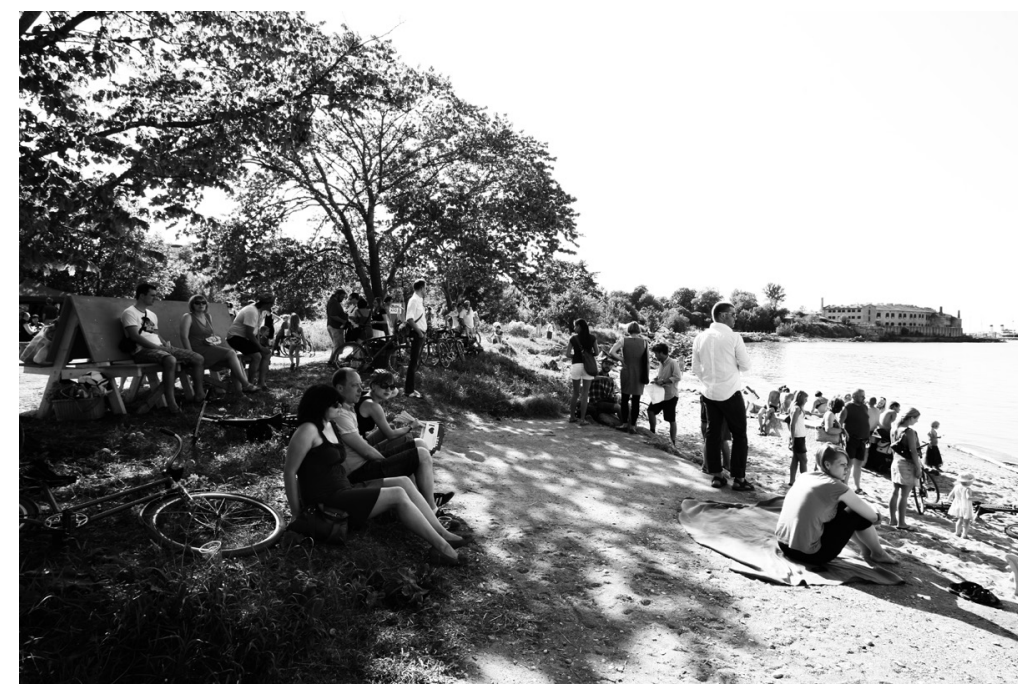

2.4 Kalarand beach, part of Lift 11 project in Tallinn (CC AI_0586) 
Acting in Groningen, the Netherlands, SpareSpace transforms vacant shops and office buildings into mobile offices. The company uses specially designed foldable furniture by designer Jack Brandsma. Focusing on young creatives, it provides affordable and representative offices for new entrepreneurs and added cultural valorization for the otherwise vacant space. As soon as the vacant space is put up to let or for sale, the entrepreneurs will move to a new building.

In the Eastern parts of Germany, demographic shrinking and related economic downturn are commonplace. In Leipzig, various temporary, place-based art interventions have been used to create a political discussion platform to address the effects of shrinking. In Magdeburg, the municipality closed and demolished a district centre with a library. In 2005, KARO Architekten proposed on the site a simple lightweight open air library and reading place, where citizens could bring books. The project became eventually so successful that in 2008-09 the municipality, with special support from Ministry of infrastructure, Building and City Development, built a permanent open air citizen's library, following $1: 1$ the temporary model.

Detroit is one of the mostly discussed examples of a shrinking city. The collapse of the motor industry has resulted in a 60 per cent decline in the city population. The flight of the population and the outflow to suburban satellites has resulted in very high rate of vacant land, abandoned homes and deserted industrial areas within the city limits - with nothing to replace them with. A radical solution has been to allow the development of urban agriculture as a temporary response to urban decline. Urban farming has evolved mainly as a community initiative, aiming to reduce poverty and support social inclusion. ${ }^{22}$

Renew Newcastle (Australia) is also a fantastic example of local creative agency in an adversary situation. (See below for a detailed description.)

\section{PUBLIC AUTHORITIES APPROACHES TO TEMPORARY USES}

One common theme in temporary uses literature has been the public authorities desirable policy to enable temporary uses as a test-bed for particular sites. In Temporary Urban Spaces, Arlt suggests that both the independent actors who seek to manage temporary uses and the public authority which seeks to set the guidelines of urban development should work as tacticians, who skilfully collaborate with other actors, property owners, visitors and media. The authorities increasingly lack the resources to simply command urban development, which also forces them to tactical allies to achieve their ends. 
Figure 3 Temporary uses in areas losing significance

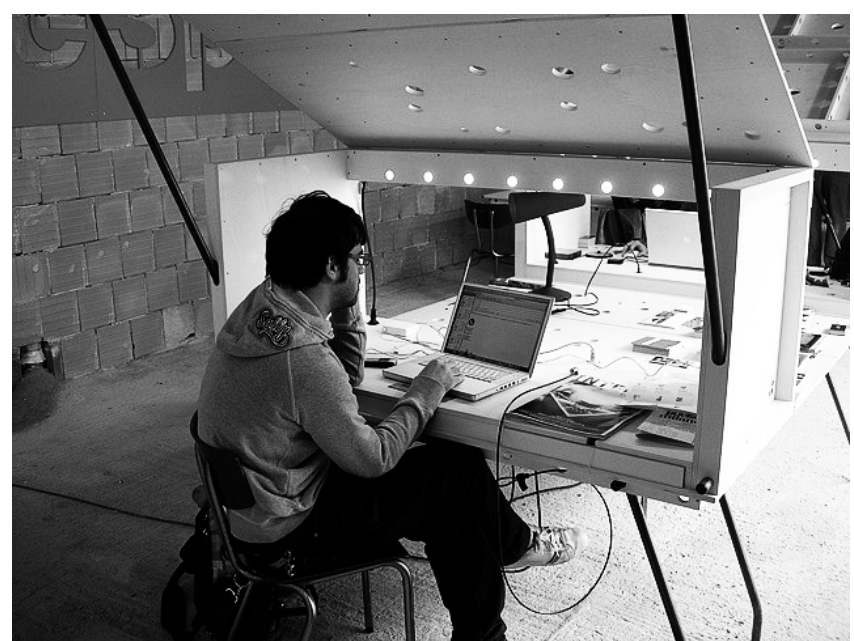

3.1 Spare Space temporary office furniture (CC BigChief Design)

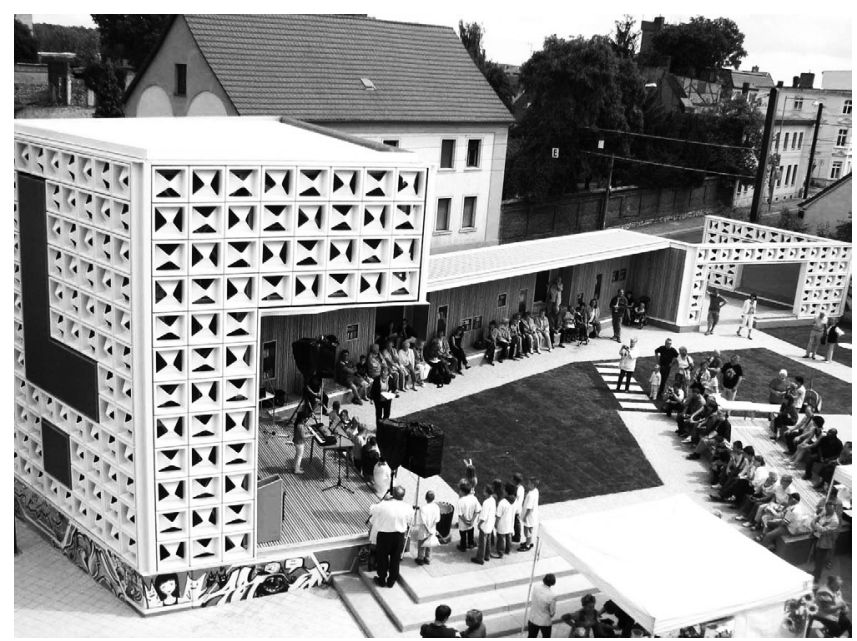

3.2 Magdeburg open air library (CC Channelbeta),

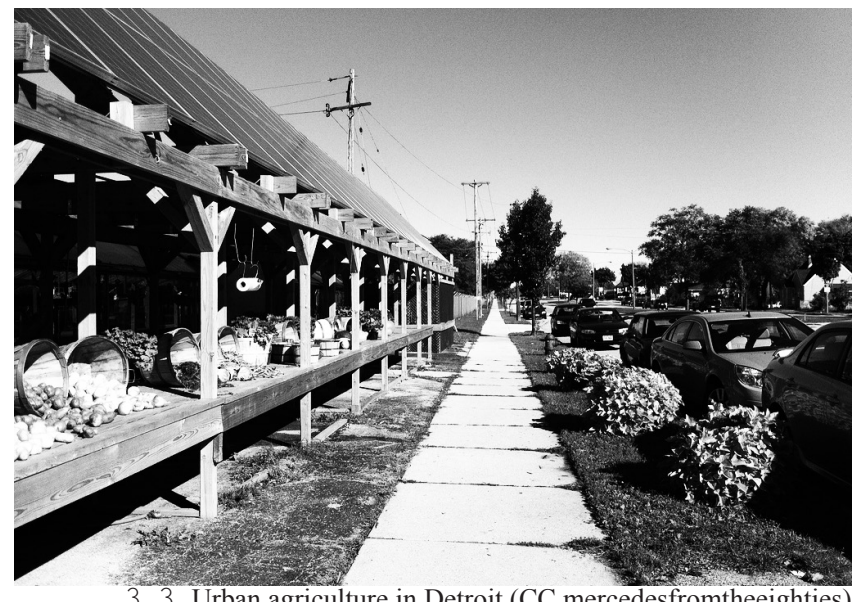


Urban Pioneers emphasise the facilitating role of a local authority. ${ }^{23}$ This means that it "can improve the overall framework by adapting urban planning tools and models to meet temporary users specific requirements". ${ }^{24}$ The local authority can commission different agents to implement temporary use or simply tolerate a spontaneous development. Bishop and Williams argue that in our times of less public resources available and weaker economic perspectives ahead, master planning should change towards "a loosely defined end vision, rather than a fixed state", which would enable "phased development often as a range of temporary stages along a more flexible path". ${ }^{25}$ Design is not any more three-, but four-dimensional, they argue; it has to take into account phasing strategies, plan the temporal as well as the physical.

In our analysis, we have identified four kinds of approaches that the public authorities have taken to incorporate temporary uses in development of particular areas. These are (1) consistent, (2) project-based, (3) centralisedidealistic and (4) best practices approach, illustrated in Table 2. The first and the fourth approach show tactical elements, as defined above, while the second and third approach reveal only partial understanding of potential benefits on the authorities' side and leave unclear the will to collaborate further.

Table 2 Public authorities approaches to temporary uses in strategic planning and development

\begin{tabular}{|c|c|c|c|c|}
\hline & CONSISTENT & $\begin{array}{l}\text { PROJECT - } \\
\text { BASED }\end{array}$ & $\begin{array}{l}\text { CENTRALISED- } \\
\text { IDEALISTIC }\end{array}$ & $\begin{array}{l}\text { BEST } \\
\text { PRACTICES }\end{array}$ \\
\hline STRATEGY & $\mathrm{X}$ & $\mathrm{X}$ & $\mathrm{X}$ & $\uparrow$ \\
\hline $\begin{array}{l}\text { IMPLEMENTA- } \\
\text { TION }\end{array}$ & $\mathrm{x} \downarrow$ & $\mathrm{O}$ & - & $X$ \\
\hline
\end{tabular}

\section{Consistent approach}

In the consistent approach, temporary use is applied as part of a long-term vision for regeneration, and implemented with adequate resources. Moreover, authorities follow the process carefully, adjusting accordingly their plans and policy to developing needs. In Amsterdam, the NDSM Wharf is a school book example of consistent strategic approach to temporary uses. Funded by City Breeding Places Fund (Broedplaatsfond Amsterdam BPA) and run as a means of promoting the urban creative economy, NDSM has become a catalyst with city-wide and even regional significance. 
The main actor has been the Municipality of Amsterdam North (SDAN). In 1999, SDAN launched an open ideas competition with a strong brief in favour of creative industries. The council wished to both re-establish a degree of control over the area and catalyse new developments. The area is close to the centre of Amsterdam, but separated from it by the Ij waterway. The competition was won by Kinetisch Noord, an alliance of artists, performers and architects that combined skills of Amsterdam former squats. Their winning concept anticipated dividing the 20,000-square-metre hall and adjacent open dock ramps into four thematic zones. The group provided the basic infrastructure for studios and workshops, which were completed by the end users.

SDAN also contributed to the area's development by lobbing the City of Amsterdam to provide a passenger ferry to link it to the city centre across $\mathrm{Ij}$, and subsidised the ferry itself for the first two years. The municipality also renovated itself one building for restaurant and office use and introduced container student housing next to NDSM. As a part of the Urban Catalyst project, the municipality commissioned STEALTH Unlimited to prepare a strategy for the application of temporary use in the area as part of a long-term vision for regeneration. Recently the area has started to attract a wider range of more established users, such as large offices and studios of MTV - to the extent that the "alternative" character of NDSM is endangered. ${ }^{26}$

Project-based approach

In the project-based approach temporary use is applied as part of a long-term vision for regeneration, but implemented only with limited resources in eventlike manner. Hence, it is unclear whether authorities are able to develop the potential further, even after a successful project. The link to policy-development is also unclear. All in all, the use of this approach is often an option due to widespread use of large-scale events to promote urban and regional change as well as the availability of project-based rather than permanent finance on culture-led initiatives. ${ }^{27}$ In Tallinn, the capital of Estonia, the project Lift 11, realised as part of Tallinn 2011 European Capital of Culture (further ECoC), is an example of project-based approach.

To regenerate the industrial waterfront and open the city towards the Baltic Sea has been one of Tallinn most important planning challenges for the last 25 years - with no realised urban projects until year 2011. During the ECoC year, however, one focus area of cultural policy programming was the transformation-anticipating seashore. ${ }^{28}$ Building a new walking path 
called "cultural kilometre" in the formerly inaccessible waterfront, and locating many inventive projects, including Lift 11, in its vicinity, have had a considerable influence on the perception of the area as well as social practices of using the space. This is visible also after the ECoC year has finished, although the environmental art projects like Lift 11 are no longer maintained. Lift 11 executed four projects on the waterfront, drawing the attention to the environment enjoyable attributes like nearness of the sea, open vistas, recreation and people-centred activities - all this in an area formerly considered derelict, inaccessible and uninviting - basically waiting for large investment schemes in a crumbled state. As one result, the development plans of the area have drawn more attention by the locals, wanting to secure at least some recreational options there also in the future.

\section{Centralised-idealistic approach}

The centralised-idealistic approach describes a situation when the idea of temporary uses is understood on a strategic level, but the resources have not been distributed for its implementation. Neither is the tactical idea of collaboration used, because the power is kept centralised. An example of this approach is activation plan of Helsinki Kruunuvuorenranta development area.

After implementing smaller-scale construction-time activation measures in some locations, including different visualisation projects of large construction sites and a project-based approach to temporary uses in Kalasatama, Kruunuvuorenranta is the first new development area where the City of Helsinki has sought to implement temporary uses in planned, phased and strategic mode. Kruunuvuorenranta is a suburban coastal area, used by oil refineries until 2011, which will be development to a new residential area of 11,000 inhabitants by the 2020s. The authorities commissioned an activation plan from WSP consultants, with the goal to increase the attractiveness of the area by giving a priority to public spaces provision in the regeneration process. ${ }^{29}$ The plan makes an overview of area's existing strengths, presents an overall as well as phased plan for activation and more detailed account on construction matters and costs. ${ }^{30}$ The planned public space includes recreational areas, such as walking and biking paths and beaches, as well as an event area including remodelling one oil container into indoor event space. Nonetheless, in the city-level project finances, no resources have been allocated to prioritize the public spaces provision, i.e. constructing them before other development takes places, not to mention collaborative measures on site. Instead, to celebrate the Helsinki World Design Capital, a light artwork is commissioned in the area in 2012. It will make the site visible from the city centre, over a sea bay, to point how near it actually is, but it will not activate the site. 


\section{Best practices approach}

The best practices approach evolves when a local temporary project is taken as a model for broader policy-making and subsequent implementation. An example is Renew Newcastle project which gave a start to a broader Renew Australia policy initiative. (Another version of best practices approach is to give initially temporary project a permanent status in particular location, after its consideration as crucial for the place.)

Newcastle (Australia) is a small city whose Central Business District (CBD) was losing popularity and becoming vacant. In the Renew Newcastle project a non-profit company was established in 2008 as intermediary agent to find short and medium term uses for buildings that are vacant, disused, or awaiting redevelopment. The aim has been to find artists, cultural projects and community groups to use and maintain these buildings and to generate activity, until they become commercially viable or are redeveloped. Renew Newcastle started operating in 2009 and by December 2011 it had 71 projects installed in 42 vacant or unused spaces in the $\mathrm{CBD}$. While non-commercial temporary uses have paid no or small rents, they have created a positive change in atmosphere, bringing the people back to formerly scarcely populated mall and streets. Consequently it has helped remaining commercial businesses to succeed, and moreover, encouraged new businesses to settle again in the area. ${ }^{31}$ After inspiring several similar vacant space revitalisation schemes across Australia, the model has served as a basis of setting up a new national social enterprise Renew Australia to provide a support, consultancy and training services to communities around Australia and the owners of vacant properties. It works to take otherwise vacant shops, offices, commercial and public buildings and use them available to incubate short-term use by artists, creative projects and community initiatives. ${ }^{32}$

\section{CONCLUSIONS}

Contemporary economic, social and cultural trends have increased interest in temporary uses of properties and urban space. Research has addressed dynamics driving temporary uses, their explorative and experimental character in developing urban places, their vital role in supporting urban diversity and the desired role of regulation and support by public authorities. Temporary uses have agreed to have notable public and commercial benefits. Although one central motivation is rise of real estate values, temporary uses are not just another gentrification story. ${ }^{33}$ They rather create new public places, support collaborative practices and nourish bottom-up approaches in urban 
development. From architectural point of view, temporary structures provide interesting area of study and experimentation. Furthermore, creative and adaptive reuse of old buildings and structures provides different, subtle and nuanced aesthetics.

Policy-makers should support the conditions of temporary uses, but refrain from much intervention in the activities. In the end, to explore potentials of a place, temporary uses primarily require cheap spaces and freedom from constraints. It is place-specific, user-centric and experiment-driven development activity. Yet that maybe nourished with suitable regulation and support mechanisms.

Temporary uses are most valuable tool in developing challenging locations, where regular real estate development is not an option for one reason or another. In our contribution we have provided a temporary uses typology. When designed and implemented in urban central areas, currently under-used areas or areas losing significance, temporary uses operate in different socio-spatial conditions and the goals are tuned to accordingly either for intensification, initiation or redefinition of the site. This typology fits to all cases mentioned in this article, but also all others that we have ever experienced ourselves, or read or heard about.

It is easier to implement or allow temporary uses in a development process, if it is agreed to proceed in phases, and it follows a strategy with an iterative rather than an end-state approach. Both the managers of temporary uses and the public authorities (e.g. planners) have been advised to take a tactical approach, i.e. collaborate with others to achieve their goals. In our contribution, we have identified four kinds of approaches the public authorities have taken to incorporate temporary uses in urban development. These are consistent, projectbased, centralised-idealistic and best practices approach. The consistent as well as best practices approaches incorporate tactical elements in a persistent way, while the project-based and centralised-idealistic approaches reveal only partial understanding of potential benefits on the authorities side and leave unclear the will to collaborate further.

We wish that our temporary uses typology, based on the socio-spatial context, and identification of different kinds of public authorities approaches, based on local policy environment, sharpens academic discussion about temporary uses as a measure of experimental urban planning. We also hope it helps practitioners to find more niches for projects that altogether make our cities more liveable. 

Mhairi Ambler, "Europe's City Beaches as Post-Fordist Placemaking." Journal of Urban Design 15 (2010) : 515-537, Panu Lehtovuori and Sampo Ruoppila. Kaupunkikiihdytin* tilapäiset käytöt kehittämisen voimavarana (Temporary uses as resource of urban development). Ympäristöministeriö, kaupunki-innovaatiot ohjelma, 2011. Peter Bishop and Lesley Williams, The Temporary City (London: Routledge, 2012). Lehtovuori and Ruoppila, 2011.

Panu Lehtovuori, Helka-Liisa Hentilä, and Christer Bengs.’Tilapäiset käytöt-kaupunkisuunnittelun unohdettu voimavara / Temporary uses - the forgotten resource of urban planning." Publications in the Centre for Urban and Regional Studies C58 (Espoo: Helsinki University of Technology, 2003):26-27.

Ibid., 31-33.

Jennifer Gerand, “Temps welcome," Planning (2007): 24-27.

Daniel Campo,"Brooklyn's Vernacular Waterfront.” Journal of Urban Design 7 (2002): 171-199.

Urban Pioneers. Berlin: Stadtentwiclung durch Zwischennutzung / Temporary Use and Urban Development in Berlin. (Berlin: Senatsverwaltung für Stadtentwicklung, 2007): p. 23. 
Ibid.,24-25.

Ibid., 9.

Lieven Ameel and Sirpa Tani, "Everyday aesthetics in action. Parkour eyes and the beauty of concrete walls." in Emotion, Space and Society (xxx), 1-10. 2011, and Quentin Stevens, The Ludic City. Exploring the Potential of Public Spaces (New York: Routledge, 2007).

Lehtovuori et al. (2003): 29.

Lehtovuori and Ruoppila, 2011.

Kimmo Ylä-Anttila, ed., Urban Fallows. Transformations \& Breeding Grounds. City Scratching III (Tampere: Tampere University of Technology, School of Architecture, EDGE Laboratory for Architectural and Urban Research, 2010).

Sampo Ruoppila, "Eastern European cities in the making - temporary land use as a tool for cultural projects," Journal for Northeast Issues 3 (2004): 24-26.

Bishop and Williams, The Temporary City, 25.

Bishop and Williams, The Temporary City, 35.

Klaske Havik, Véronique Patteeuw and Hans Teerds, "Editorial: Productive uncertainty / Indeterminacy in spatial design, planning and management." OASE 85 (2011): 3-6.

Ruoppila et al., Infrastructures for Innovation: Enhancing Innovation Activity through Urban Planning in Baltic Metropolises, 17.

Bishop and Williams, The Temporary City, 174.

Quentin Stevens and Mhairi Ambler, "Europe's City Beaches as Post-Fordist Placemaking," Journal of Urban Design 15 (2010) : 515-537.

Gerend, 2007.

Bishop and Williams, The Temporary City,158-159.

Urban Pioneers, 2007.

Ibid., 159.

Ibid., 179.

Urban Pioneers 2007, 110 and Bishop and Williams, The Temporary City, 176-177.

Davide Ponzini and Sampo Ruoppila, "What's the "city" in the design and implementation of the European Capital of Culture? An open issue,” Tafter Journal 42 (electronic journal), 2011.

Tarmo Pikner, "Spatialisation of urban culture in a large-scale event: urban visions and the program of Tallinn 2011 European Capital of Culture.” Tafter Journal 42 (electronic journal), 2011.

Ibid., 7.

WSP. Kehittyvä kaupunginosa: Kruunuvuorenrannan aktivoinnin suunnitelma (Activation Plan of Kruunuvuorenranta City District). Osa 1. Raportti, 17.12.2010. Commissioned by the City of Helsinki, Economic and Planning Centre, 2010.

Helen Gregory, "City‘s heart beats again," Newcastle Herald, December 17, 2011.

http://renewnewcastle.org/

Quentin Stevens and Mhairi Ambler, "Europe's City Beaches as Post-Fordist Placemaking," Journal of Urban Design 15 (2010) : 515-537. 
Ameel, Lieven and Sirpa Tani. "Everyday aesthetics in action. Parkour eyes and the beauty of concrete walls." in Emotion, Space and Society (xxx), 1-10. 2011. Available online, http:// dx.doi.org/10.1016/j.emospa.2011.09.003

Arlt, Peter. "Urban planning and interim use". In Temporary Urban Spaces, edited by Florian Haydn and Robert Temel, 39-46. Basel: Birkhäuser, 2006.

Bishop, Peter, and Lesley Williams. The Temporary City. London: Routledge, 2012.

Blumner, Nicole. Planning for the Unplanned: Tools and Techniques for Interim Use in Germany and the United States. Deutsches Institut für Urbanistik, Occasional Papers, 2006.

Campo, Daniel. “Brooklyn's Vernacular Waterfront.” Journal of Urban Design 7 (2002): 171-199.

Gerand, Jennifer. "Temps welcome.” Planning (2007): 24-27.

Gottdiener, Mark. Theming of America. Boulder: Westview Press, 1997.

Gregory Helen. "City's heart beats again.” Newcastle Herald, December 17, 2011. Available at http://renewnewcastle.org/static/files/assets/c478a26e/11.12.17_herald_citys_heart_beats_ again_interview_w_marni_jackson.pdf

Havik, Klaske, Véronique Patteeuw and Hans Teerds. "Editorial: Productive uncertainty / Indeterminacy in spatial design, planning and management." OASE 85 (2011): 3-6. 
Haydn Florian. "A material that never comes to rest. Concepts and potentials of temporary spaces." in Temporary Urban Spaces, edited by Florian Haydn and Robert Temel, 67-73. Basel: Birkhäuser, 2006.

Haydn, Florian and Robert Temel. eds. Temporary Urban Spaces: Concepts for the Use of City Spaces. Basel: Birkhäuser, 2006.

Lang Ho, Cathy. "Hold this site." Architect, June (2010): 32-36.

Lehtovuori, Panu, Helka-Liisa Hentilä, and Christer Bengs.”Tilapäiset käytöt kaupunkisuunnittelun unohdettu voimavara / Temporary uses - the forgotten resource of urban planning." Publications in the Centre for Urban and Regional Studies C58. Espoo: Helsinki University of Technology, 2003.

Lehtovuori, Panu and Sampo Ruoppila. Kaupunkikiihdytin* - tilapäiset käytöt kehittämisen voimavarana (Temporary uses as resource of urban development). Ympäristöministeriö, kaupunki-innovaatiot ohjelma, 2011. Available (in Finnish) at http://www.kaupunki-innovaatiot. fi/wp-content/uploads/2011/11/kaupunkikiihdytin_pieni2.pdf

Pikner Tarmo. "Spatialisation of urban culture in a large-scale event: urban visions and the program of Tallinn 2011 European Capital of Culture.” Tafter Journal 42 (electronic journal), 2011. Available at http://www.tafterjournal.it/2011/12/05/spatialisation-of-urban-culture-in-alarge-scale-event-urban-visions-and-the-program-of-tallinn-2011-european-capital-of-culture/

Ponzini, Davide and Sampo Ruoppila. "What's the "city" in the design and implementation of the European Capital of Culture? An open issue.” Tafter Journal 42 (electronic journal), 2011. available at http://www.tafterjournal.it/2011/12/05/what $\%$ E2\%80\%99s-the- $\% E 2 \% 80 \% 9 \mathrm{C}$ city $\% \mathrm{E} 2 \% 80 \% 9 \mathrm{D}$-in-the-design-and-implementation-of-the-european-capital-of-culture-anopen-issue/

Raban, Jonathan. Soft City. London: The Harvill Press, 1974.

Ruoppila, Sampo. "Eastern European cities in the making - temporary land use as a tool for cultural projects." Journal for Northeast Issues 3 (2004): 24-26. (Available at http://www. kaupunkikettu.fi/temporary2004.html)

Ruoppila, Sampo, Panu Lehtovuori and Nina von Hertzen. Infrastructures for Innovation: Enhancing Innovation Activity through Urban Planning in Baltic Metropolises. Helsinki: BaltMet Inno Project, 2007.

Smith, Neil. The New Urban Frontier. New York: Routledge, 1996.

Stevens, Quentin. The Ludic City. Exploring the Potential of Public Spaces. New York: Routledge, 2007.

Stevens, Quentin and Mhairi Ambler. "Europe's City Beaches as Post-Fordist Placemaking." Journal of Urban Design 15 (2010) : 515-537.

Söderlind, Jerker. "Culture as Soft City Infrastructure.” Paper presented at International Conference for Integrating Urban Knowledge \& Practice. May 29 - June 3, 2005, Gothenburg, Sweden. Available at http://jerkersoderlind.se/PDF/9-In-English/Culture_as_Soft_City_Infrastructure_ Conference_Paper_050601.pdf

Urban Pioneers. Berlin: Stadtentwiclung durch Zwischennutzung / Temporary Use and Urban Development in Berlin. 2007. Berlin: Senatsverwaltung für Stadtentwicklung.

WSP. Kehittyvä kaupunginosa: Kruunuvuorenrannan aktivoinnin suunnitelma (Activation Plan of Kruunuvuorenranta City District). Osa 1. Raportti, 17.12.2010. Commissioned by the City of Helsinki, Economic and Planning Centre, 2010.

Ylä-Anttila, Kimmo (ed). Urban Fallows. Transformations \& Breeding Grounds. City Scratching III. Tampere: Tampere University of Technology, School of Architecture, EDGE Laboratory for Architectural and Urban Research, 2010.

Zukin, Sharon. Loft Living: Culture and Capital in Urban Change (rev.ed.). New Jersey: Rutgers University Press, 1989. 
INTERNET RESOURCES FOR THE CASES MENTIONED

(a)1 web links accessed May 2012)

Bigz: http://www.spottedbylocals.com/belgrade/bigz-building/

Helsinki WDC 2012 pavilion: http://wdchelsinki2012.fi/en/pavilion

Johan Centrum (Plzen): http://www.johancentrum.cz/en/

Kalasatama Temporary (Helsinki): http://kalasatamanvaliaika.fi/shortly-in-english and http:// tuomassiitonen.fi/archives/409

Lift 11 (Tallinn): http://www.lift11.ee/

Magdeburg open air library: http://www.archdaily.com/39417/open-air-library-karo-architekten/

NDSM Wharf (Amsterdam): http://ndsm.nl

The NYC DOT public plaza program: http://www.nyc.gov/html/dot/html/sidewalks/publicplaza. shtml and http://buildipedia.com/in-studio/urban-planning/new-york-revitalizes-the-lifebetween-buildings?print=1\&tmpl=component

Paris Pláge: http://www.paris.fr/english/visit/highlights/paris-plages/rub_8208_stand_34146_ port_18969

Platoon Kunsthalle (Berlin, Seoul, Gwangju): http://www.kunsthalle.com/

Renew Newcastle: http://renewnewcastle.org/

Spare Space (Groningen): http://www.sparespace.org/

Trapeze School New York: http://newyork.trapezeschool.com/

Urban farming: http://www.urbanfarming.org/ 


\section{SLOŽENA PRIRODA POTENCIJALNIH BUDUĆNOSTI ARHITEKTURE}

\section{Anastasios Tellios}

Arhitektura se menja, u skladu sa inovacijama i tehnološkim dostignućima alatki i metodologija projektovanja. Međutim, istraživanje i definisanje prostora i dalje ostaje njen osnovni zadatak. Tehnologija koja je dostupna arhitektama je reviolucionalizovala upravljanje morfogenetskim postupcima kroz nove tehnike modeliranja, formalne spekulacije i njeno upotpunjivanje umetničkom intuicijom. Ohrabrila je arhitekte da eksperimentišu sa konstrukcijama i morfološkim atributima prirodnih sistema i organskim kao i neorganskim oblicima i ozbiljno je uticala na odgovarajuće prostorne predoge. Nove koncepcije, uvedene u arhitektonsku diskusiju i savremeno istraživanje vođeno projektovanjem sugerišu izuzetne primere prostornih uređenja, govore o potpuno novoj arhitektonskoj stvarnosti. Prilazom preko holističkog i interdisciplinarnog spektra i još uvek zatočena unutar Arhitektonskih fakulteta, ova nova arhitektura odmerava svoj budući potencijal i šanse za stvarnu primenu.

KLJUČNE REČI: PROJEKTOVANJE VOĐENO BIOLOGIJOM, PRIRODNA ADAPTACIJA, GENERATIVNA

ARHITEKTURA, PROSTORNO ISTRAŽIVANJE, ARHITEKTONKSI NARATIV, POJAVLJIVANJE

\section{PRIVREMENE UPOTREBE KAO SREDSTVA EKSPERIMENTALNOG URBANOG PLANIRANJA}

\section{Panu Lehtovuori, Sampo Ruoppila}

Savremeni ekonomski, društveni i kuturni trendovi podržavaju interes za privremene upotrebe nekretnina i urbanog prostora. Privremene upotrebe imaju eksperimentalni karakter u izgradnji , i saglasne su da imaju puno društvenih i komercijalnih koristi, uključujući kreiranje prostora i podršku zajedničkih praksi. Ovaj članak daje tipologiju društveno-prostornih uslova i ciljeva privremenih upotreba. Kada su projektovani i implementirani u gradske centralne oblasti, trenutno nedovoljno korišćene oblasti, ili oblasti koje gube svoj značaj, privremene upotrebe se shodno tome usklađuju radi intenziviziranja, početka i redefinisanja njihovih lokacija. Identifikovana su četiri pristupa koje su javne vlasti uzele da bi obuhvatile privremene upotrebe. To su: dosledan, na projektnoj bazi, centralističko-idealistički i pristup najboljih praksi. 